\title{
The effect of good corporate governance and financial performance on the health score of regional development banks in Indonesia
}

\author{
W. Perwitasari \& E. Kritijadi \\ STIE Perbanas Surabaya, Indonesia
}

\begin{abstract}
Bank health reflects the condition and performance that need to be considered. A bank has to be healthy to get customers' trust. The indicator of a healthy bank is showing good performance or achievement during a certain period. It can be influenced by factors such as GCG, PBBA, PNBA, ALR, KKR, and MI. This study aims to find out the simultaneous and partial effects of GCG, PBBA, PNBA, ALR, KKR, and MI on bank health. The population of the study was regional development banks in Indonesia in 2014-2018. The technique used in this study was purposive sampling involving six regional development banks as the samples of the study. The data were analyzed using multiple linear regression. The results showed that GCG and MI had no positive effect on bank health; while PBBA, PNBA, and ALR had no significant negative effect. Moreover, KKR had a negative significant effect on bank health.
\end{abstract}

\section{INTRODUCTION}

The health scores of 26 regional development banks (RDBs) in Indonesia from 2014 to 2018 showed a downward trend. This means that there are still problems with the RDBs, especially with their health. Hence, research is needed to find out the factors influencing the health score decline. This study aims to determine the significance of the simultaneous effects of the composite scores of GCG, PBBA, PNBA, ALR, KKR, and core capital on the soundness level of RDBs in Indonesia.

Research on health by Aryanti and Balafir (2007) concluded that the NPL ratio had a significant effect on the probability of a bank being healthy and unhealthy, while the CAR, ROA, ROE, and NIM ratios showed insignificant effects on bank health. Haryati explained that of the 27 analysis variables, only 16 were significantly discriminant against the health level of national public and private banks. Sukarno (2011) explained that the performance of PT Bank DKI, based on its financial ratios, was classified as a liquid, quite solvable, profitable, and efficient commercial bank; but it was unstable in handling business risks. Using CAMELS, PT Bank DKI gained the soundness level of "healthy," which means that the bank was classified as a good bank and able to overcome the negative effects of economic conditions and the financial industry. However, the bank still had minor weaknesses that could be resolved immediately with routine action. Lutfi et al. (2014) explained the role of the board of commissioners and transparency in financial and nonfinancial conditions in operational efficiency. In terms of efficiency, only a properly functioning board of commissioners is able to increase the bank operation efficiency. As for profitability, the boards of commissioners and public transparency are also able to increase the profitability of banking operations in Indonesia. Sri Haryati and Kristijadi (2014) explained that the risk profile did not have a significant and positive effect on financial performance. Among the four risk profiles, liquidity risk had the best discriminatory validity. However, GCG had a significant and positive effect on financial performance, and only financial and non-financial transparency had the best convergent validity. Five indicators of bank financial performance had good validity. In addition, ROA, NIM, and CAR had good validity, in which ROA had the highest estimated loading. Mongid et al. (2012) used three stages of analysis in their research. In the first stage of analysis, INEFF was 
regressed against CAP, RISK, SIZE, and OBSTA. In the second stage, RISK was regressed against CAP, INEFF, SIZE, and NLTA. In the third stage, CAP was regressed against RISK, INEFF, SIZE, ROA, and IRC. The results showed that CAP and SIZE were negatively associated with inefficiency. However, surprisingly, RISK was insignificant. In the risk equation, the results showed that CAP and INEFF were negatively associated with risk. In the modal equation, there was a negative relationship between CAP and RISK but not with INEFF. Sufian and Noor (2012) explained that empirically, credit risk, network attachment, operating costs, liquidity, and size statistically had a significant impact on bank profitability in India. Yung (2009) found that banks with larger board sizes with lower related party borrowing rates tended to perform well. In addition, bank size is positively related to bank performance, which indicates that the bigger the bank, the better is its performance. Other findings indicated that banks listed on the stock exchange showed better performance than unlisted banks.

\section{THEORETICAL FRAMEWORK AND HYPOTHESIS}

The hypothesis used in this study is that the composite scores of GCG, PBBA, PNBA, ALR, KKR, and MI have a simultaneous significant effect on the health score of RDBs in Indonesia. The GCG composite score, PBBA, PNBA, ALR, KKR, and the adequacy of MI have a partially significant positive effect on the health score of RDBs in Indonesia. The bank soundness level is the result of the assessment of the bank's condition with respect to the risk and performance of the bank. Banks are required to assess the soundness level using a risk-based approach (risk-based bank rating), either individually or on a consolidated basis (Regulation of the Financial Services Authority Number 4 /POJK.03/2016).

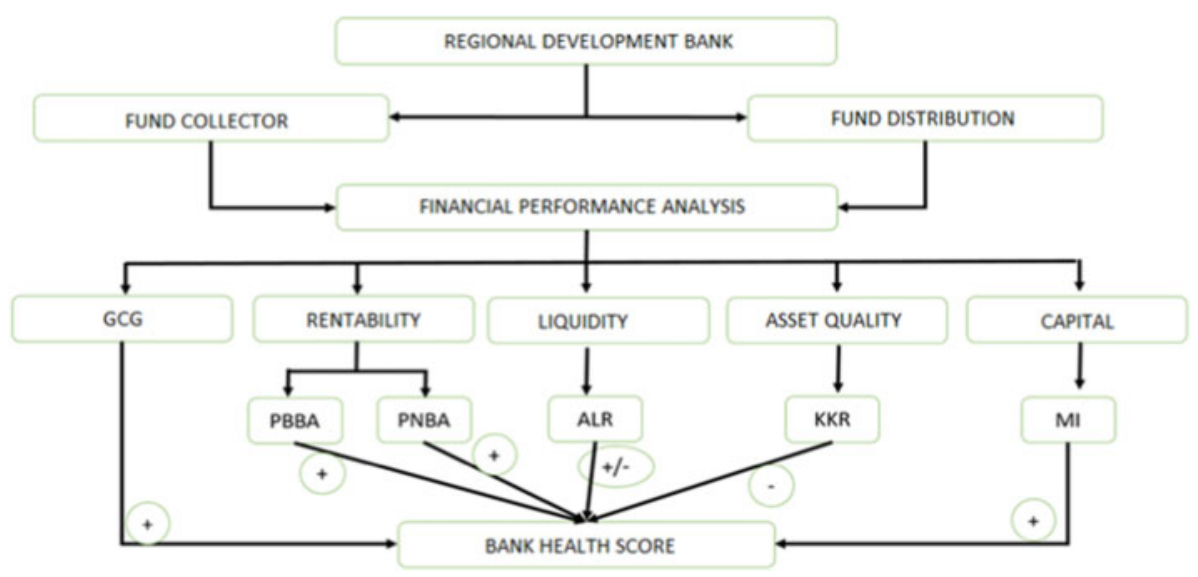

Figure 1. Research framework

\section{RESEARCH METHOD}

The population in this study is 26 regional development banks in Indonesia. The technique used in this study is the purposive sampling method. The sample selection criteria were as follows: banks in the Business Group II, having a core capital of over two trillion rupiahs, and having experienced a decline in health scores. Based on the criteria, six RDBs were selected as samples, namely, Bank Pembangunan Daerah (BPD) Kalimantan Barat, BPD Sumatera Barat, BPD Riau and Kepulauan Riau, BPD Bali, BPD Sulawesi Selatan dan Sulawesi Barat, and BPD Papua. 
The analysis technique used is multiple linear regression with the following regression equation:

$$
\mathrm{Y}=\alpha+\beta_{1} \mathrm{GCG}+\beta_{2} \mathrm{PBBA}+\beta_{3} \mathrm{PNBA}+\beta_{4} \mathrm{ALR}+\beta_{5} \mathrm{KKR}+\beta_{6} \mathrm{MI}+\mathrm{ei}
$$

\section{RESEARCH RESULTS}

Table 1. Regression Coefficient

\begin{tabular}{lrrrlll}
\hline & & & & & \multicolumn{2}{l}{ Conclusion } \\
\cline { 5 - 6 } Variable & \multicolumn{1}{c}{$\mathrm{t}_{\text {count }}$} & $\mathrm{t}_{\text {table }}$ & $\mathrm{r}$ & $\mathrm{r}^{2}$ & $\mathrm{H}_{0}$ & $\mathrm{H}_{1}$ \\
\hline GCG & 0.760 & 1.714 & 0.156 & 0.024 & H0 accepted & H1 rejected \\
PBBA & -0.816 & -1.714 & -0.168 & 0.028 & H0 accepted & H1 rejected \\
PNBA & -0.829 & -1.714 & -0.170 & 0.029 & H0 accepted & H1 rejected \\
ALR & -0.553 & -1.714 & -0.115 & 0.013 & H0 accepted & H1 rejected \\
KKR & -5.090 & -1.714 & -0.728 & 0.530 & H0 rejected & H1 accepted \\
MI & 0.255 & 1.714 & 0.053 & 0.003 & H0 accepted & H1 rejected \\
\hline
\end{tabular}

GCG had a partially insignificant effect on bank health. The insignificance is because the banking sector had a low level of good corporate governance. Banks implement GCG not merely to fulfill their necessity, but also because of compliance with existing regulations. Indeed, good corporate governance will have a good impact on companies, so that it can indirectly improve the earnings quality or financial performance, which in turn can improve the company value in the eyes of investors and parties who lend money to the company. Therefore, companies can get a loan easily if they need funds to maintain their operations and reduce risks for shareholders, and it can also increase competitiveness in the global market.

PPBA had a partially insignificant effect. This is because during the period of 2014 to 2018 , there was a very small change in the PPBA of the research sample banks. This condition showed that the better the PPBA obtained by the banks, the lower is the banks' health score. This result is certainly not in line with the theory stating that the higher the PPBA value, the greater is the banks' ability to generate net interest income using their assets so that the banks' health score also increases. In addition, PNBA partially had no significant effect on bank health. This is because in general, the non-interest income earned by regional development banks is very low.

ALR had a partially insignificant effect on bank health. This is due to the low average ALR level of these banks. This reflects the banks' low ability to meet their maturing obligations using primary liquid assets and secondary liquid assets, while the banks' level is generally healthy. A high ALR level indicates a higher ability to meet maturing obligations by relying on primary liquid assets and secondary liquid assets as sources of liquidity. This high ALR can result in a large amount of unused capital, so that the RDBs' opportunity to gain profits is also lost and the health score decreases.

KKR had a partially significant effect on bank health. This means that the higher the KKR level, the lower is the banks' health score. This relationship is in line with the theory stating that a higher KKR level indicates the lower ability of banks to manage credit quality, and it will have an impact on the earning interest income, which will lead banks to form provision expenses, and so the bank's health score decreases.

MI had a partially insignificant effect on bank health. This result shows that the banks could not effectively manage their core capital to increase income. In addition, the banks could not reduce costs incurred during operations, so that even though the core capital increases, the resulting income could not be maximized if it is accompanied by an increase in costs. 


\section{CONCLUSIONS, RECOMMENDATIONS, AND LIMITATIONS}

The GCG variable had a partially positive and insignificant effect. PBBA, PNBA, and ALR variables had no significant negative effect. KKR had a significant negative effect. MI had a positive and insignificant effect on bank health scores in 2014-2018.

This research on RDBs in Indonesia has several limitations: the research period used was 20142018; the number of variables studied was limited (GCG, PPBA, PNBA, ALR, KKR, and MI) and other variables in the Infobank research bureau, including LDR, NPL, IRR, PDN, BOPO, and FBIR, were not used. The research subjects were only limited to the six RDBs, BPD Kalimantan Barat, Sumatra Barat, BPD Riau dan Kepulauan Riau, BPD Bali, BPD Sulawesi Selatan and Sulawesi Barat, and BPD Papua. Further research can be more representative by expanding the research subjects.

\section{REFERENCES}

Abdul Mongid, Izah Mohd Tahir, Sudin Haron. 2012. The Relationship between Inefficiency, Risk and Capital Evidence from Commercial Banks in ASEAN. International Journal of Economics and Management, Vol. 6, No. 1, 2012, p. 58-74.

Anwar Sanusi. 2013. Metodologi Penelitian Bisnis. Cetakan Ketiga. Jakarta: Salemba Empat.

Fadzian Sufian, Mohamad Akbar Nor. 2012. Determinants of Bank Performace in a Developing Economy: Does Bank Origin Matters?. Global Business Review, Volume: 13 issue: 1, page(s): 1-23.

Juliansyah Noor. 2013. Metodologi Penelitian. Jakarta: PT Kencana Prenada Media Group.

Kasmir. 2010. Manajemen Perbankan. Jakarta: PT. Raja Grafindo Persada.

Kasmir. 2012. Manajemen Perbankan. Edisi Revisi. Jakarta: PT Raja Grafindo Persada.

Lutfi, Melyza Silvy, Iramani. 2014. The Role of board commissioners and transparency in improving bank operational efficiency and profitability. Journal of Economics, Business, \& Accountancy Ventura. Vol. 17, Number 1, p. 81-90.

Majalah Infobank pada periode 2014 sampai dengan 2018, mengambil data pada tanggal 7 Juni 2020.

Mo Fung Yung. 2009. The Relationship Between Corporate Governance and Bank Performance in Hongkong. Master Dissertation at Auckland University of Technology, 2009.

Otoritas Jasa Keuangan dan Publikasi Bank (Online). (www.ojk.go.id). Diakses pada tangal 14 Juni 2020.

Peraturan Otoritas Jasa Keuangan nomor 4 /POJK.03/2016 tentang Penilaian Tingkat Kesehatan Bank Umum (Online). (www.ojk.go.id), diakses pada tanggal 14 Juni 2020.

Rosady Ruslan. 2010. "Metode Penelitian Public Relations dan Komunikasi". Cetakan Kelima. Jakarta : PT. Raja Grafindo Persada.

Sri Haryati, Emanuel Kristijadi. 2014. The Effect of GCG implementation and Risk Profile on Financial Performance at Go Public National Commercial Bank. Journal of Indonesian Economy and Business. Vol. 29. Number 3, 2014, P. 237-250.

Sugiono. 2012. "Metode Penelitian Kuantitaf Kualitatif dan R\&B". Bandung: Alfabeta. 